\title{
ISLAND-MAINLAND NEXUS: THE CASE OF THE COASTAL LIVELIHOOD OF TINGLOY ISLAND AND THE SOUTHWESTERN PORTION OF BATANGAS, PHILIPPINES
}

\author{
EDGAR M. REYES JR*
}

\author{
Department of Community and Environmental Resource Planning, College of Human Ecology University of the Philippines Los Baños, \\ Philippines; Landscape Ecology and Landscape Planning, School of Spatial Planning, Technical University of Dortmund, Pulverstr 23, \\ 44225 Dortmund, Germany \\ * Corresponding author: edgar.reyes@tu-dortmund.de
}

\begin{abstract}
This research explored the natural resources available to the island municipality of Tingloy, Batangas. It looks at fisheries as the economic resource of an island and how this activity is linked in with the larger economic context of the mainland. Tingloy is a rural settlement the livelihood of which is dependent on fishing and its spatio-economic links with the mainland through fisheries. Fishing is the subsistence economy of Tingloy, with the surplus exported to the mainland. However, a fishery product flow analyses showed that the fishermen of Tingloy are marginalized by the disproportionate distribution of the income in favour of middlemen and fish dealers. Support facilities (such as ports, cold storage, processing units, trading posts, etc.) to further improve the local economy of the island is limited and must be upgraded. Also, transport facilities and other infrastructures to assure the integration of the local-regional economic function of the island municipality must be carefully crafted. Interventions to further improve the local economic condition of the island and its integration with that of the mainland are directed towards improved institutional arrangements, stricter implementation of existing local ordinances, and regional development planning that would take a holistic view and consider the vast resource base of the local government units.
\end{abstract}

Keywords: island-mainland interaction; livelihood; natural resources; spatio-economic linkage; spatial planning

\section{Introduction}

Islands provide several unique ecosystem services (provisioning, regulating, supporting, cultural/aesthetic, etc.) important for the sustained development of a larger spatial landscape. According to Agenda 21, small islands are strategically important environments and the development of their resources need to be properly managed.

The reality that island ecosystems are fragile and vulnerable emphasizes the need for island management. Sustainable island management as an approach will provide the means to conserve the natural functions of island ecosystems. Furthermore, effective island management will define the synergistic development of the island and the larger regional spatial landscape it interacts with.

Among the many amenities supplied by the island ecosystem include fishery resources that sustain the livelihood of local communities. A study on the Pacific Coast of North America by Fitzhugh and Kennett (2010) shows two concurrent major factors in the small-island and mainland interaction over time: (1) the degree of socio-economic self-sufficiency of island populations and (2) the nature of resource distribution and the socio-political dynamics. Issues of island isolation emerge if consequences of these interactions are not resolved. However, another more relevant dilemma is the consequence of the distribution of the gains from which inequality emanates. The centre-periphery continuum is very evident in the context of an island-mainland spatial interaction (Grydehoj 2014).

In addition, the government pays little or no attention to small island systems leading to the continuing threat of isolation from the mainland because they are located far from political and economic centers (CCS et al. 2011). In the Philippine archipelagic landscape, there are many small islands the development of which must be properly integrated into the national spatial planning and development agenda. Many small islands in the Philippine archipelago are neglected and little prioritized even if they are of outstanding ecological, economic or social value. The problem of human development, subsistence economy, land tenure and management, governance and institutional issues are common phenomenon in small island systems in the Pacific (Schoeffel 1996).

The goal of this paper is to show the disparity in the economic resource exchange between an island and the mainland in terms of fishery resources using the case of Tingloy Island municipality and the Southwestern Batangas province in the Philippines.

\section{The Island of Tingloy in the context the Southwestern Batangas (mainland)}

\section{The natural coastal/marine resources of Tingloy Island}

Islands are usually rich sources of fishery products. This is true, especially for Pacific islands, including the archipelago of the Philippines, an area that is teeming with a rich marine biodiversity. Various fish stocks are harvested by the fishermen in this municipality and this is affected in several ways: (a) although a wide array of fish are present, the actual catch of each fish stock also varies and changes based on what is actually available; (b) the catch is very much attuned to the daily survival of 
the fishermen, who characteristically maintain a smallscale fishing activity (Smith et al. 1983); and (c) the harvest of fish by the fishermen of Tingloy is very variable because they use traditional fishing gear/equipment. An estimated 105 tons of fishery resources (75 tons of fish and 30 tons of squid) are harvested by the island municipality of Tingloy.

Barangay (the term used to specify the smallest political unit in the Philippines, is equivalent to a village) coastal water fishing is especially relevant as they use non-motorized boats and shoreline fishing. The common fishing grounds of the majority of the fishermen on Tingloy are the easternmost and westernmost parts of the island, and the open waters of Balayan Bay, Batangas Bay and the Verde Island Passage (Fig. 1).

There are a variety of fish stocks available and harvested in the fishing grounds surrounding the island (Table 1). The reef fish and other seafood (squid, octopus, etc.) in the fishing grounds surrounding the island are the source of the main harvest. According to the fishermen of Tingloy, the catch of fish during the months of November to May (Amihan season) is better than in the rest of a year. This is due to the prevailing winds/monsoon influencing the capacity of fishermen to harvest fish (Alix 1976; Castillo 2011) and it has a huge effect on the availability of the marine biodiversity for harvesting, especially in the case of the Philippine archipelago (Barut et al. 2003).

\section{The challenges for Tingloy Island}

The traditional fishing technologies used by the island population are not seen as a challenge; however, with the limiting of the areas that can be harvested and encroachment of fishermen from other municipalities, some fishermen opt to use motorized and large-scale fishing activities in order to survive. The introduction of new fishing methods frequently leads to a decline in fish stocks and the impoverishment of many traditional subsistence fishermen (Quinn 2009). In addition, the monsoon dictates the kinds of fish in the fishing grounds since fish are highly dependent on wave action and direction of the prevailing wind.

The other problem with this economic resource is that freshly caught products must be sold to middlemen, because of the lack of electricity on the islands prevents the fishermen storing and further processing their catch. These limits are imposed disproportionately by people with strong ties to urban and big city populations who direct the development of rural island economies (Lichter and Brown 2011). The limits in terms of facilities result in island communities suffering from the unbalanced financial distribution of their resources.

The local fishermen must be encouraged to form cooperatives and organize themselves to maximize their earnings from the products they sell. The significant effect of fishery cooperatives on fish income reveals that fishery cooperatives do serve their purpose by improving

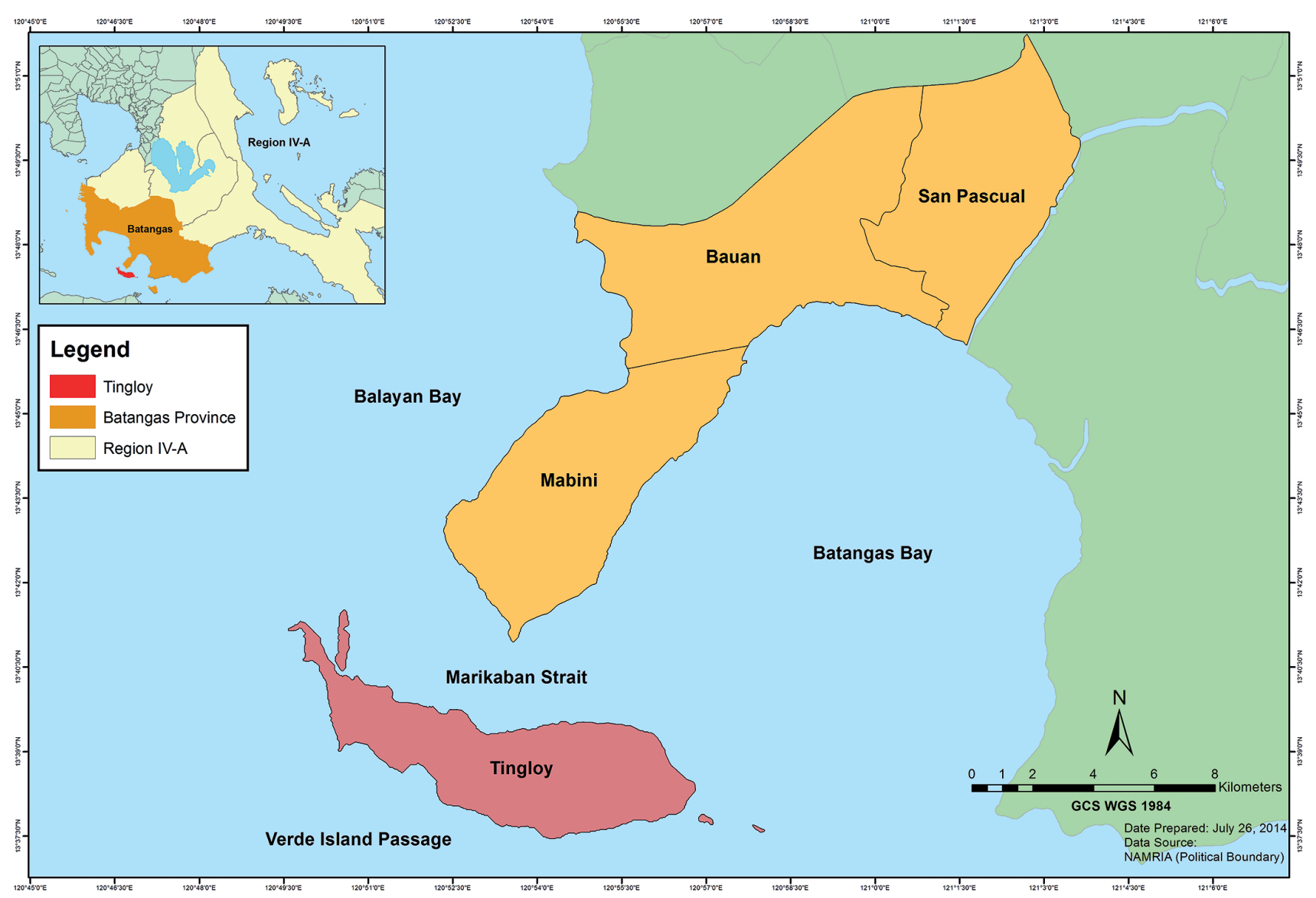

Fig. 1 Map showing the location of Tingloy Island and the Southwestern Portion of Batangas, Philippines. 
Table 1 List of the main fish stocks harvested in Tingloy waters during the monsoon season.

\begin{tabular}{|c|c|c|}
\hline Fish Stocks/Species (Local Names*) & Northeast Monsoon (Amihan) & Southwest Monsoon (Habagat) \\
\hline $\begin{array}{l}\text { goby (burot-burot), yellowtail fusilier (dalagang bukid/buglaw), scad } \\
\text { (galunggong), skipjack tuna (gulyasan), flat needlefish (kambabalo), sur- } \\
\text { geon fish (labahita), flying fish (bolador/lagidlid), grouper (lapu-lapu), long- } \\
\text { jawed mackerel (alumahan), purse-eyed scad (matangbaka), red snapper } \\
\text { (maya-maya), trevally/jack/cavalla (talakitok/maliputo/muslo), yellow fin } \\
\text { tuna (tambakol), spanish mackerel (tanigue), mackerel tuna (tulingan) }\end{array}$ & $=$ & $=$ \\
\hline $\begin{array}{l}\text { long-jawed mackerel (alumahan), anchovy (dilis/balakwas), short-bodied } \\
\text { mackerel (hasa-hasa), starry triggerfish (pakpakan/pigit/pakol), sardinella } \\
\text { (tamban) }\end{array}$ & $<$ & $>$ \\
\hline $\begin{array}{l}\text { sea bream (bakoko), big eyes snapper (burara), needle fish (batalay/ham- } \\
\text { babalo), threadfin bream (bisugo), grouper (kulapo), black or white marlin } \\
\text { (malasugue), bigeye trevally (manitis), blue marlin (layag-layag), celebes } \\
\text { threadfin bream (tingin) }\end{array}$ & $>$ & $<$ \\
\hline starry gobi (dulong), parrot fish (purak-purak, loro), tuna (pusing) & $\checkmark$ & $x$ \\
\hline
\end{tabular}

(*) Local names and English translations are based on those in fishbase.org.

$(<)$ Indicates that the catch of a specified fish stock is less in the monsoon season.

$(>$ ) Indicates that the catch of a specified fish stock is greater in the monsoon season.

$(=)$ Indicates that the catch of a specified fish stock is the same in both monsoon seasons.

$(\checkmark)$ Indicates that these species are usually only caught during this monsoon season.

$(x)$ Indicates that they are very seldom caught in this particular monsoon season.

the monitoring of fishing efforts, creating better market opportunities, providing greater bargaining power or reducing transaction costs (Garoma et al. 2014).

\section{The comparative advantage of Southwestern Batangas}

The Southwestern Batangas is composed of three municipalities: Mabini, San Pascual and Bauan (Fig. 1). These municipalities collectively support the provincial capital and an international port. Services provided by these municipalities include transport and communication services, manpower and human resources, processing, manufacturing and marketing, etc. These are the general economic activities of the three municipalities making up Tingloy Island, which is the raw material goods provider, especially of fishery resources.

Infrastructure development and access to a larger market are among the few advantages of the Southwestern portion of Batangas compared to the island municipality of Tingloy, which is geographically isolated. Physical infrastructure such as road networks, market, cold storage, electricity and post-processing facilities are abundantly available. As investment in production factors became attractive, the former major restriction on fish production, poor transport conditions, mostly disappears (Olsson 2009). These advantages (southwestern Batangas) made it easier for the mainland to assume the role of post-processing and marketing of raw material goods harvested by the island municipality. This further defines the island municipality as rural settlements in the province of Batangas that provide the larger human settlements with agricultural and raw materials.

Access to a larger market, through improved road networks and transportation facilities, is obvious on the mainland. In a similar study, the existence of an adequate and efficient road network is crucial and a prerequisite of access and provision, thereby providing easier movement for citizens and a means of alleviating poverty (Fan and Chan-Kang 2008). People can easily reach the markets and trading posts on the mainland, where raw fishery goods are stored. Resort owners and restaurants that require fresh fish also go to the coastal areas of the mainland (Southwestern portion of Batangas), which make these locations strategic sites for the exchange of goods.

\section{Movement of Fishery Products between the Island and the Mainland}

\section{Flow of fishery products}

Tracing the movement of fishery products from the fishing grounds to where they are consumed reveals a specific route (Fig. 2).

The fishery product flow from Tingloy starts in the fishing grounds, where fish, squid and octopus are caught. These are then moved by the fishermen to the middlemen (casa). The fishermen can be placed in one of three categories: (a) those that rent or borrow a boat for them to be able to fish (mamamalakaya); (b) those that have an agreement with the middleman that enables them to have a boat on loan, so long as their daily fish catch goes directly to the middlemen as a form of payment for the boat; (c) those independent fishermen who own their boat and choose to either use the middlemen or go directly to the market or trading posts to sell their fresh goods. This is not only a characteristic of Tingloy Island, as the study of Agbebi and Fagbote in 2012 indicates that middlemen control most of the market. The many functions performed by the middlemen include the following: maintaining contact with buyers, negotiating prices, delivery, transfer of title; providing credit or collecting money, servicing of products; providing an inventory and storage and arranging transportation. 
After being sorted and transported by the middlemen at the trading posts, fish dealers buy and trade the produce on a wholesale basis. These fish dealers and vendors transport these products to the markets in the adjacent municipalities. Sometimes, consumers buy directly from the trading posts in order to have a better choice of fish at a lower price. This fishermen-middlemen interaction is another example of the patron-client relationship, wherein, the patron (middlemen) benefits from such a relationship by an assured supply of a produce (Lim et al. 1995).

The diagram (Fig. 2) also shows the spatial division of the flow of fishery products. The upper part of the diagram, showing the actual fishing activity up to when it reaches the middlemen is mainly the concern of the island municipality of Tingloy. The trading and consequent distribution of these fishery products occurs on the mainland. Mabini is the common drop-off point of the fish catch from Tingloy Island and from there, the distribution flows from the Markets of Mabini, Bauan and San Pascual. The spatial allocation of the activities may also imply the extent of the extraction of natural resources, clearly, in this case, much of this occurs on the island and in surrounding areas, whereas, the financial benefits that could protect or conserve these resources do not come back to this area.

This movement of fishery products is mainly within the region except when the catch is sufficient for the fish dealers to transport it to Batangas City. However, in the case of squid, the product flow extends to Batangas City as the demand there for squid is higher.

\section{Spatial linkage of island and mainland}

Providing a spatial dimension for the flow of fishery products entails tracing the actual movement of the products from one place to another. Fig. 3 shows the actual flow of fishery products in space. This is represented by the lines coming from the island municipality. The lines surrounding the island municipality shows that the fish caught on the fishing grounds are brought back to the island municipality for local consumption. The lines extending from the municipality to the mainland and other areas show the outward flow of fishery products. Buying and selling freshly caught fishery products is an informal trade within the island municipality. Often, only the excess fish is sold to the local communities as the best quality fresh products are directly sold to the middlemen.

The outward flowing lines from the island municipality of Tingloy to the mainland represent the economic linkages between the island municipality and the mainland. The economic flow, in terms of the fishery products, are clearly indicated on the map in Fig. 2. The established links between the island municipality and mainland are: (a) Tingloy- Mabini (Anilao and Talaga) for the region under consideration; (b) Tingloy-Lemery, for the linkage, however seldom, between the island municipality and other municipalities on the mainland; (c) Tingloy-Batangas City, both direct and through land transportation (Tingloy-Mabini-Batangas City); this linkage is very evident especially in the flow of squid; (d) Tingloy-Verde Island (Small Islands linkages), Verde Island is under the jurisdiction of Batangas City where several barangays are situated; and (e) Tingloy-Mindoro (Calapan City and Puerto Galera), are economic linkages driven by the booming tourism on the island province of Mindoro.

The economic linkages between Tingloy and the mainland are manifested in the physical link between

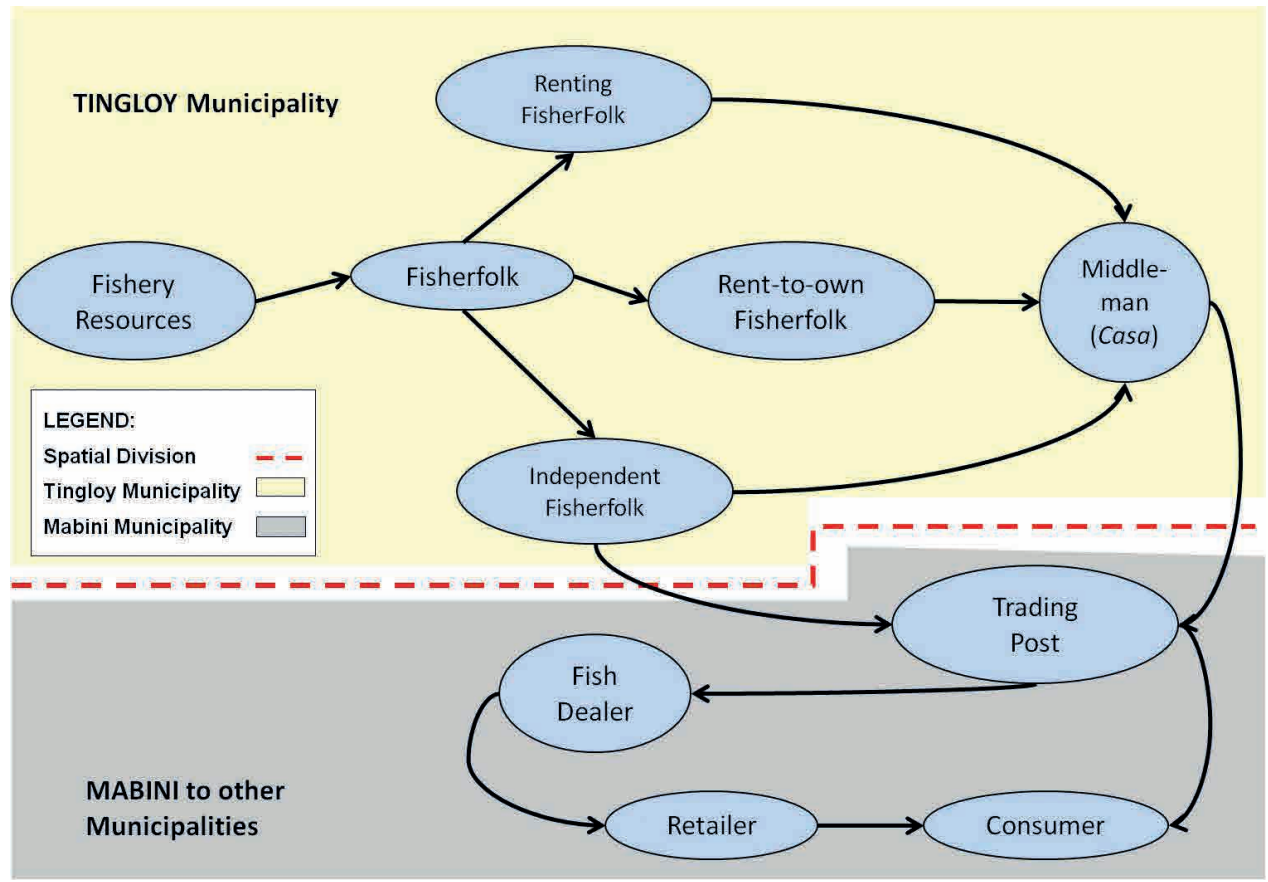

Fig. 2 Fishery product flow between Tingloy Island and the southwestern Batangas. 


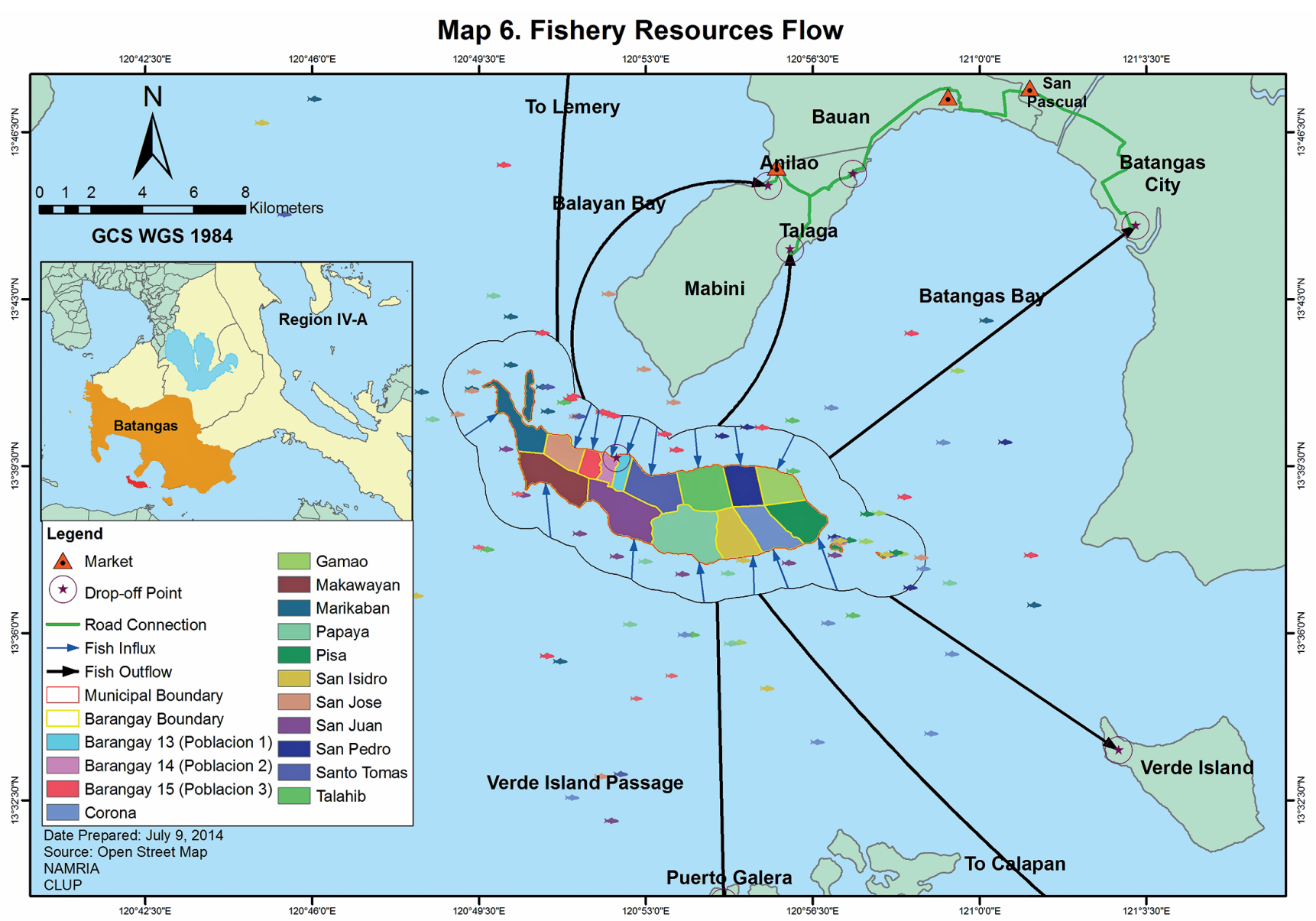

Fig. 3 Flow of fishery products in the region.

Tingloy and Mabini. This linkage is a well-established sea-route for the transport of people using motorized-boats. There are two (2) ports in the municipality of Mabini (on the mainland) that are used to connect to the island municipality of Tingloy. Fish landing sites are also present in Mabini, whereas, in the island municipality of Tingloy, only poor quality fish landing sites are available.

Since the markets of the municipalities of Bauan and San Pascual are alongside a road this results in a spillover interaction in the existing economic flow between Tingloy and Mabini. Road networks connecting Mabini-Bauan-San Pascual to Batangas City also make it possible for fishery products to flow within the region (mainland).

Given such conditions and the integration of the flow of fishery products, then the expectation is that income and employment opportunities will increase throughout the wider community (World Bank 2006). Such an expansion is championed by the 2014 study of Nshimbi and Vinya in 2014, which emphasizes that it must include the management of natural resources, improvements, diversification in agriculture, agroforestry and ecotourism (World Bank 2006), and the provision of an efficient marketing system. However, the organization and management of these resources seems to need more time for full integration.

\section{Valuation of fishery resources}

The existing interaction between the island municipality and the mainland through fishing activity can be further analysed using a value chain analysis. This tool differs from commodity flow analysis as it centres on the monetary or value added to a particular resource flowing through a system. Furthermore, value chain analysis focuses on systems, and how inputs are changed into the outputs that are purchased (Porter 1985). Since the product in the flow under consideration is a primary or raw material, its value is not increased very much (Table 2).

The commodity starts to incur added value only during transportation by the middleman. The added value for such a commodity is attributed primarily to the costs of transporting the goods from one place to another and the service fees charged by the middleman. The same occurs in the later stages where the commodity incurs added value right up to when it is consumed. The fishermen cannot impose prices for their commodities as they are usually determined by the patron-client agreement existing between them and the middlemen.

In Table 2, it is clear that although there is an economic linkage between Tingloy and the mainland, the distribution of the actual income from the commodity is not even, because the fishermen are marginalized. The value placed on the intensive labour input of the eco- 
nomic activity of Tingloy fishermen is less than that on the mainland employment involved with distribution and sale of the same commodity (fishery products) in the region.

Looking closely at the value chain analysis, a range totalling PhP 20.00-40.00 for fish products and PhP 20.0030.00 for squid per kilogram is the gross income of the middlemen (50.00 PhPeso $=1.00$ US Dollar/2016). If this is calculated in terms of the minimum number of kilograms transacted in the trading post (50 kilograms) and deducting all other expenses (transportation and other fees) they incur, the net income of the middlemen is $\mathrm{PhP}$ 1684.00 to 3184.00 per day.

The fish dealers and vendors, have an income of $\mathrm{PhP}$ 20.00 per kilogram for fish products and $\mathrm{PhP} 60.00$ 80.00 for selling a kilo of squid. Taking a minimum of 50 kilograms of fish products sold by fish dealers/vendors in the market and deducting all other costs, the net income of the fish dealers and/or vendors is PhP 3440.00 for fish products and PhP 4000.00 for squid.

In addition, the price of the fishery products is dictated by the middlemen and in other studies conducted by Bryceson in 1993 and Visser in 2015, the earnings of middlemen is considerably greater because they control in the market. Also, the collection and consequent reselling of products to the vendors is also controlled by the middlemen, which forces the fishermen to directly deal with the market (Agbebi and Fagbote 2012). Bystrom in 2014 also shows that for the traditional fishing activity, the entire catch of snappers can be priced at US\$ 1.50 per fish, which end up in local resort Restaurant's plate at around US\$25.00 per fish. A similar situation leave Tingloy fishermen with little control over their condition. Furthermore, the fishermen are also limited by the uncertainty of their catch caused by the conditions imposed by the natural environment and the capacity of the fishing gear they use.

\section{Conclusion}

The island municipality's role on the mainland (Mabini, Bauan and San Pascual) is that of a rural settlement providing raw materials. Tingloy provides fishery products for livelihood generation. This synergy extends even far beyond the three municipalities under consideration and includes Batangas City and the municipality of Lemery. This physical link is very evident through the established buying and selling of fishery products. However, the benefits from fishing are not properly distributed resulting in the marginalization of fishermen in Tingloy, this is clearly manifested in the commodity

\begin{tabular}{|c|c|c|c|c|c|c|c|c|c|c|}
\hline \multirow{2}{*}{ STACES } & \multirow[t]{2}{*}{ Description } & \multirow[t]{2}{*}{ Units Accounted } & \multicolumn{2}{|c|}{$\begin{array}{l}\text { Number of } \\
\text { Units Used }\end{array}$} & \multicolumn{2}{|c|}{$\begin{array}{l}\text { Price per Unit } \\
\text { (PhP) }\end{array}$} & \multicolumn{2}{|c|}{ Total Cost (PhP) } & \multicolumn{2}{|c|}{$\begin{array}{c}\text { Value Addition } \\
\text { (PhP) }\end{array}$} \\
\hline & & & Min & $\operatorname{Max}$ & Min & $\operatorname{Max}$ & Min & $\operatorname{Max}$ & Min & $\operatorname{Max}$ \\
\hline eparation & $\begin{array}{l}\text { Preparatory Activities for fishing } \\
\text { activities (Maintenance of Input, } \\
\text { buying of inputs required }\end{array}$ & $\begin{array}{l}\text { Motorized Boat } \\
\text { Fishing Gear (Set) } \\
\text { Man Power }\end{array}$ & $\begin{array}{l}1 \\
2 \\
2\end{array}$ & - & $\begin{array}{c}96 \\
25 \\
100\end{array}$ & $\dot{-}$ & $\begin{array}{c}96 \\
50 \\
200\end{array}$ & $\dot{-}$ & $\begin{array}{l}- \\
-\end{array}$ & - \\
\hline Fish Catching & $\begin{array}{c}\text { The actual activity of catching } \\
\text { Fishery resources }\end{array}$ & $\begin{array}{l}\text { Fisherman's Food } \\
\text { Fisherman's Water } \\
\text { Fish Bait (set) }\end{array}$ & $\begin{array}{l}2 \\
2 \\
1\end{array}$ & $\begin{array}{l}- \\
-\end{array}$ & $\begin{array}{c}20 \\
20 \\
100\end{array}$ & $\begin{array}{l}- \\
-\end{array}$ & $\begin{array}{c}40 \\
40 \\
100\end{array}$ & $\begin{array}{l}- \\
-\end{array}$ & $\begin{array}{l}- \\
-\end{array}$ & $\begin{array}{l}- \\
-\end{array}$ \\
\hline $\begin{array}{l}\text { orting and } \\
\text { Storing }\end{array}$ & $\begin{array}{c}\text { Collation of fishes and other catch } \\
\text { and consequent storing in } \\
\text { containers }\end{array}$ & $\begin{array}{l}\text { Fish Containers } \\
\text { Plastic Cover }\end{array}$ & $\begin{array}{l}2 \\
2\end{array}$ & $\dot{-}$ & $\begin{array}{l}1 \\
1\end{array}$ & $\dot{-}$ & $\begin{array}{l}2 \\
2\end{array}$ & $\dot{-}$ & $\dot{-}$ & $\dot{-}$ \\
\hline $\begin{array}{c}\text { Sea } \\
\text { Transportation }\end{array}$ & $\begin{array}{l}\text { Transportation of Fish and other } \\
\text { catch from the fishing grounds to } \\
\text { the middleman }\end{array}$ & $\begin{array}{l}\text { Gasoline for } \\
\text { motorized boat } \\
\text { (Liters) }\end{array}$ & 2- & - & $\begin{array}{l}60 \\
- \\
-\end{array}$ & - & $\begin{array}{c}120 \\
- \\
-\end{array}$ & $\begin{array}{l}- \\
-\end{array}$ & $\dot{-}$ & $\begin{array}{l}- \\
-\end{array}$ \\
\hline $\begin{array}{l}\text { Collection of } \\
\text { Fish Products }\end{array}$ & Collection by the middleman & $\begin{array}{l}\text { Fishes (kilogram) } \\
\text { Squid (Kilogram) }\end{array}$ & $\begin{array}{l}3 \\
5\end{array}$ & $\begin{array}{c}7 \\
15\end{array}$ & $\begin{array}{l}80 \\
30\end{array}$ & $\begin{array}{l}120 \\
100\end{array}$ & $\begin{array}{l}240 \\
150\end{array}$ & $\begin{array}{c}840 \\
1,500\end{array}$ & $\dot{-}$ & \\
\hline $\begin{array}{l}\text { Transportation } \\
\text { by middleman }\end{array}$ & $\begin{array}{l}\text { Movement from the middleman } \\
\text { bringing to the trading posts }\end{array}$ & $\begin{array}{l}\text { Motorized Boat } \\
\text { Gasoline } \\
\text { Other Fees }\end{array}$ & $\begin{array}{l}1 \\
2 \\
1\end{array}$ & $\dot{-}$ & $\begin{array}{c}96 \\
60 \\
100\end{array}$ & $\dot{-}$ & $\begin{array}{c}96 \\
120 \\
100\end{array}$ & . & $\begin{array}{l}- \\
.\end{array}$ & $\dot{-}$ \\
\hline $\begin{array}{l}\text { Wholesaling } \\
\text { by middleman }\end{array}$ & $\begin{array}{l}\text { From the trading post, the } \\
\text { middleman will sell the catch in } \\
\text { bulk }\end{array}$ & $\begin{array}{l}\text { Fishes (kilogram) } \\
\text { Squid (Kilogram) }\end{array}$ & $\begin{array}{l}3 \\
5\end{array}$ & $\begin{array}{c}7 \\
15\end{array}$ & $\begin{array}{c}100 \\
60\end{array}$ & $\begin{array}{l}160 \\
120\end{array}$ & $\begin{array}{l}300 \\
300\end{array}$ & $\begin{array}{l}1,120 \\
1,800\end{array}$ & $\begin{array}{c}60 \\
150\end{array}$ & $\begin{array}{l}280 \\
300\end{array}$ \\
\hline $\begin{array}{l}\text { Retailing Fish } \\
\text { Products }\end{array}$ & $\begin{array}{c}\text { From Wholesale trade to the fish } \\
\text { vendors in the market }\end{array}$ & $\begin{array}{l}\text { Jeepney } \\
\text { Gasoline } \\
\text { Manpower }\end{array}$ & $\begin{array}{l}1 \\
2 \\
1\end{array}$ & $\dot{-}$ & $\begin{array}{c}400 \\
60 \\
100\end{array}$ & $\dot{-}$ & $\begin{array}{l}400 \\
120 \\
100\end{array}$ & $\dot{-}$ & $\begin{array}{l}- \\
-\end{array}$ & $\begin{array}{l}- \\
-\end{array}$ \\
\hline $\begin{array}{c}\text { Final } \\
\text { Consumption }\end{array}$ & $\begin{array}{l}\text { Market Fish vendors selling the } \\
\text { fish catch to the consumes }\end{array}$ & $\begin{array}{l}\text { Fishes (kilogram) } \\
\text { Squid (Kilogram) }\end{array}$ & $\begin{array}{l}3 \\
5\end{array}$ & $\begin{array}{c}7 \\
15\end{array}$ & $\begin{array}{l}120 \\
120\end{array}$ & $\begin{array}{l}180 \\
200\end{array}$ & $\begin{array}{l}360 \\
600\end{array}$ & $\begin{array}{l}1,260 \\
3,000\end{array}$ & $\begin{array}{c}60 \\
300\end{array}$ & $\begin{array}{c}140 \\
1,200\end{array}$ \\
\hline
\end{tabular}

Table 2 Value chain of the fishery products in Tingloy, Batangas. 
flow diagram. Furthermore, the income from the fishing activity mainly goes to the middlemen and retailers on the mainland.

This results in a spatial divide in the economic benefits between the island and mainland. Furthermore, with limited economic opportunities, some implications for the fishermen of Tingloy are the evident exhaustion of their subsistence economic resource and the over exploitation of other fishery resources. Also, the overworking of the fishermen is to be expected.

\section{Recommendations}

\section{Improved coastal management/stricter enforcement of municipal water laws and protection of the MPAs}

The following must be done simultaneously: (a) conservation of fishing grounds using sustainable fishing technologies; (b) restoration and increase in the number of people manning the area, (b) improve marine protected areas (MPAs) by zoning; (c) buildings for the local coast guards and for training people in effective conflict management, provision of basic incentives for workers (health and emergency funds, insurance, etc.), increase in the work force among the local coast guards; (d) alternative livelihood generation that will cater for both the fishermen and the local community.

\section{Storage and further processing of fishery products on the island}

Storage facilities for maintaining the quality of freshly caught fish could enable fishermen to avoid wastage when catches are high. Processing of goods into more valuable products must be complemented by improving the techniques used in harvesting or catching fishery products by packaging those that are harvested in municipal waters. Strategic branding and marketing of fishery products could further promote the products of the region that are not only competitively priced in the local market but also internationally.

\section{Creation}

Fishing cooperatives can be especially important for the management of sustainable fisheries, especially in areas where governance is weak (Rife 2015). Middlemen should be an integral part of the cooperative in order to assure their participation and reassure them that their role will not be taken over by the cooperative. The characteristics of the cooperative should be: (a) members are the fishermen at the barangay level and the middlemen; (b) it must have an information-base, using mobile phones, or any other simple yet effective means of communication; (c) have strong links with the trading posts on the mainland; (d) have a source of finance available for funding all members, plus an emergency fund; and (e) continuously train staff in cooperative management, building team rapport and managing finances.

\section{REFERENCES}

Agbebi FO, Fagbote TA (2012) The role of middlemen in fish marketing in Igbokoda fish market, Ondo-state, south western $\mathrm{Ni}$ geria. International Journal of Development and Sustainability 1: $880-888$.

Alix JC (1976) Survey of fish catch landed and unloaded at the Navotas fish landing and market authority in Navotas, Metro Manila. Fish Res J Philipp 1: 50-61.

Barut NC et al. (2003) Philippine Coastal Fisheries Situation. In: Silvestre G, Garces LR, Stobutzki I, Ahmed M, Valmonte-Santos RA, Luna C, Lachica-Aliño L, Munro P, Christensen V, Pauly D (eds). Assessment, Management and Future Directions for Coastal Fisheries in Asian Countries. ICLARM, Manila, Philippines. pp 885-914.

Bryceson DF (1993) Liberalization of Tanzania food trade: Public and Private faces of urban marketing policy (1938-1988). United Nations research institute for social development. Geneva, Switzerland.

Bystrom A (2014) Development of the Bejuco Bottom Longline Snapper Fishery, Northern Pacific Coast, Costa Rica: A Replicable Solution to the Uncertain Economic Future of Costa Rica's SmallScale Fisheries. In: McConney P, Medeiros R, Pena M (eds) Enhancing Stewardship in Small Scale Fisheries Practices and Perspectives (CERMES Technical Report No. 73), pp 150-152.

Castillo RC (2011) When Fishing is No Longer Viable: Environmental Change, Unfair Market Relations, and Livelihood in a Small Fishing Community in the Philippines, Bielefeld. Center on Migration, Citizenship and Development (COMCAD) Working Papers (105). http://www.uni-bielefeld.de/tdrc /ag_comcad/downloads/Rosa-Castillo_panel-4.pdf.

Coastal CORE Sorsogon (CCS), Marinduque Council for Environmental Concerns, Social Action Center Northern Quezon (2011) Introduction: Why Focus on Small Islands. In: Clemente-Aran MD (ed) A Voyage to Disaster Resilience in Small Islands: A Guide for Local Leaders. Christian Aid-Philippine Office, Quezon City, Philippines, pp 1-2.

Fan S, Chan-Kang C (2008) Regional road development, rural and urban poverty: Evidence from China. Transport Pol 15:305-314.

Fitzhugh B, Kennett DJ (2010) Seafaring Intensity and Island-Mainland Interaction along the Pacific Coast of North America. In: Anderson A, Barrett JH, Boyle KV (eds) The global origins and development of seafaring. Oxbow Books, Oxford, UK, pp 69-78.

Garoma D, Admassie A, Ayele G, Beyene F (2014) Analysis of the Impact of Fishery Cooperatives on Fishing Activity of Rural Households Around Lake Ziway and Lagano in Ethiopia. Middle-East J Sci Res 19: 144-162.

Grydehoj A (2017) A future of island studies. Island Studies Journal 12: 3-16

Lichter D, Brown D (2011) Rural America in an Urban Society: Changing Social and Spatial Boundaries. Annu Rev Sociol 37: 565-592.

Lim CP, Matsuda Y, Shigemi Y (1995) Problems and Constraints in Philippine Municipal fisheries: The case of San Miguel Bay, Camarines Sur. Environ Manage 19: 837-852.

Nshimbi M, Vinya R (2014) Impacts of Public-Private Partnership on Local Livelihoods and Natural Resource Dynamics: Perceptions from Eastern Zambia. Resources Journal 3: 471-487.

Olsson J (2009) Improved road accessibility and indirect development effects: evidence from rural Philippines. J Transport Geogr 17: 476-483.

Porter ME (1985) Competitive Advantage: Creating and Sustaining Superior Performance. Free Press, New York, USA. 
Quinn NJ (2009) Volume II: Traditional methods of fishing (southwest pacific). In: Squires VR (ed) The role of food, agriculture, forestry and fisheries in human nutrition. UNESCO-EOLSS, Adelaide University, Adelaide, Australia.

Rife A (2015) Mexico's successful fishing cooperatives have important lessons for small-scale fisheries globally. http://blogs .edf.org/edfish/2015/09/24/mexicos-successful-fishing-cooperatives-have-important-lessons-for-small-scale-fisheries-globally/. Accessed 10 December 2018.

Schoeffel P (1996) Socio-cultural Issues and Economic Development in the Pacific Islands. Information Office, ADB, Manila, Philippines.
Smith IR, Pauly D, Mines AN (1983) Small-scale fisheries of San Miguel Bay, Philippines: Options for management and research. ICLARM Technical Report 11. http://pubs.iclarm.net /libinfo/Pdf/Pub\%20TR4\%2011.pdf.

Visser N (2015) The origins of the present: economic conflicts in the fisheries of the South African south coast, circa 1910 to 1950. Maritime Studies 14(9). doi: 10.1186/s40152-015-0029-6.

World Bank (2006) Module 5: Investment in Sustainable Natural Resource Management for Agriculture. In: World Bank (ed) Agricultural Investment Sourcebook. Washington DC, USA. 